CZASOPISMO INŻYNIERII LĄDOWEJ, ŚRODOWISKA I ARCHITEKTURY JOURNAL OF CIVIL ENGINEERING, ENVIRONMENT AND ARCHITECTURE

JCEEA, t. XXXIII, z. 63 (3/16), lipiec-wrzesień 2016, s. 533-542

\author{
Krystyna WRÓBEL ${ }^{1}$
}

Wiesław KUBISZYN ${ }^{2}$

\title{
REMONT ZABYTKOWEGO OGRODZENIA LETNIEGO PAŁACU LUBOMIRSKICH W RZESZOWIE
}

\begin{abstract}
Letni Pałac Lubomirskich wraz z otoczeniem jest jednym z najcenniejszych zabytków architektury niesakralnej w Rzeszowie. W roku 2013 Okręgowa Izba Lekarska zakupiła Pałac od ostatnich właścicieli - rodziny Nieciów na swoją siedzibę. Zaplanowano remont całego kompleksu. Prace remontowe budynku są w toku. W 2015 roku przeprowadzono gruntowny remont ogrodzenia z uwagi na jego katastrofalny stan techniczny. Cel główny jaki przyświecał działaniom, to zachowanie (w maksymalnym możliwym stopniu) substancji istniejącej. Wyremontowano i zabezpieczono przed oddziaływaniem wilgoci gruntowej i atmosferycznej trzy strony ogrodzenia, pozostawiając stronę wschodnią. Remont polegał na naprawie i wzmocnieniu słupów od ul. Dekerta, wzmocnieniu i zabezpieczeniu przed dalszymi uszkodzeniami istniejącej ściany oporowej oraz dobudowie fragmentu ściany koniecznego do utrzymania stabilności ogrodzenia, przebudowie pozostałych słupów z dwóch stron posesji oraz murków pomiędzy słupami. Wszystkie słupy zabezpieczono głowicami żelbetowymi odwzorowującymi kształt zastanych. Odcinek frontowy, wszystkie naroża i wejście od ul. Dekerta zaakcentowano ustawiając na słupach ozdobne wazy. Wykonano nową bramę wjazdowa z wykorzystaniem elementów starej bramy, jej skrzydła ozdobiono replikami herbu Lubomirskich wykutymi w blasze, a bramkę obok bramy wykonano odwzorowując istniejącą od strony ul. Dekerta. Przęsła stalowe ogrodzenia - po naprawie i renowacji wykorzystano istniejące. W referacie szczegółowo opisano stan techniczny ogrodzenia przed remontem oraz sposób i zakres wykonanych prac remontowych.
\end{abstract}

Słowa kluczowe: stan techniczny, zabezpieczenie, korozja biologiczna, słupy, ściana oporowa

\section{Wprowadzenie}

Letni Pałac Lubomirskich w Rzeszowie został wybudowany pod koniec XVII wieku w stylu barokowym przez Hieronima Augustyna Lubomirskiego [1, 2]. Franciszek Lubomirski sprzedał Pałac wraz z otoczeniem w 1798 r. Po czym

${ }^{1}$ Autor do korespondencji / corresponding author: Krystyna Wróbel, Politechnika Rzeszowska, Katedra Konstrukcji Budowlanych, ul. Poznańska 2, 35-959 Rzeszów; tel. 178651553; wrobel@prz.edu.pl

${ }^{2}$ Wiesław Kubiszyn, Politechnika Rzeszowska, Katedra Konstrukcji Budowlanych, ul. Poznańska 2, 35-959 Rzeszów; tel. 178651553; wkubisz@prz.edu.pl 
miał on kilku właścicieli, a w latach 70-tych XX wieku został wywłaszczony. Po remoncie przeprowadzonym w 1981 roku Pałac użytkowało Miasto.

Pałac wraz z otoczeniem został wpisany do ewidencji zabytków w 1968 r. pod numerem ewidencyjnym A-292 na podstawie Karty Zabytku [2]. W roku 2013 stał się własnością Okręgowej Izbie Lekarskiej w Rzeszowie z przeznaczeniem na jej siedzibę. Wnętrza Pałacu, a następnie jego ogrodzenie poddano gruntownemu remontowi na podstawie wcześniej opracowanych projektów.

\section{Opis ogrodzenia}

Ogrodzenie otacza całą posesję przynależną do Pałacu. Z zapisków historycznych [3] wynika, że już w XIX wieku Pałac ogrodzono na nowo, wystawiono ceglane murki i słupy zwieńczone gzymsowaniem oraz wazami pochodzącymi z dawnego ogrodu kwiatowego (rys. 1).

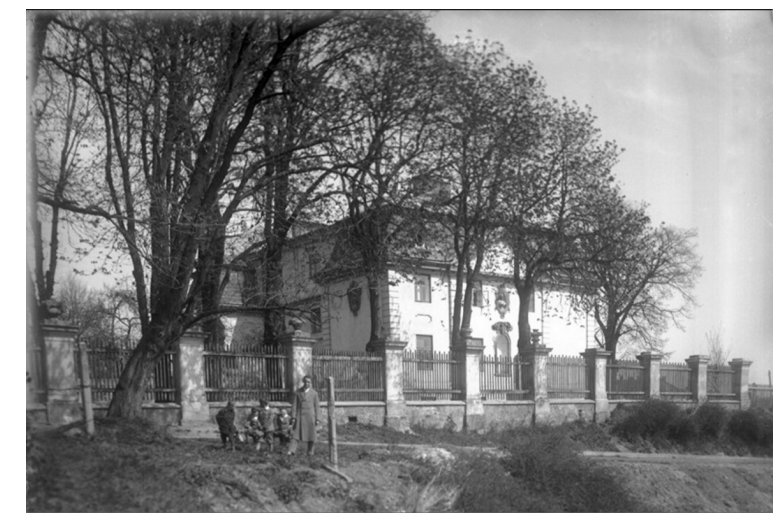

Rys. 1. Widok Pałacu i ogrodzenia od strony południowozachodniej. Rys. Edward Janusz [3]

Fig. 1. View of the Palace and the fence from the south -west. Fig. by Edward Janusz [3]

Z Karty Ewidencji Zabytku [2] wynika, że w roku 195913 szt. waz było ustawionych na ogrodzeniu od strony południowo-zachod-niej. Stopniowo ich liczbę zwiększono do 25. Na podstawie wywiadu z sąsiadami ustalono, że obecna forma ukształtowania terenu wokół Pałacu powstała w latach 60-tych poprzez podniesienie poziomu terenu od strony wschodniej o około $2,0 \mathrm{~m}$. Wówczas to przebudowano słupy ogrodzeniowe od strony wschodniej i południowej, posadawiając je na ścianie oporowej. Przęsła ogrodzeniowe drewniane zamieniono na stalowe.

Przed remontem przeprowadzonym w roku 2015 ogrodzenie było wykonane w postaci słupów ceglanych z profilowaniem i pogrubieniami przy podstawach i głowicach. Słupy były zwieńczone głowicami o różnych kształtach 
i rozwiązaniach materiałowych, betonowe - młodsze wzdłuż granicy wschodniej i południowej (powstały około roku 1960) i ceglane - starsze.

\section{Opis stanu technicznego ogrodzenia przed remontem}

Układ ogrodzenia w terenie z określeniem zakresu i etapów remontu pokazana na rys. 2 . Widok ogólny ogrodzenia przed remontem przedstawia rys. 3 . Jego stan techniczny oceniono jako katastrofalny na podstawie szczegółowych ekspertyz mykologicznej, konstrukcyjnej-budowlanej i opinii geotechnicznej zawartych w [4].

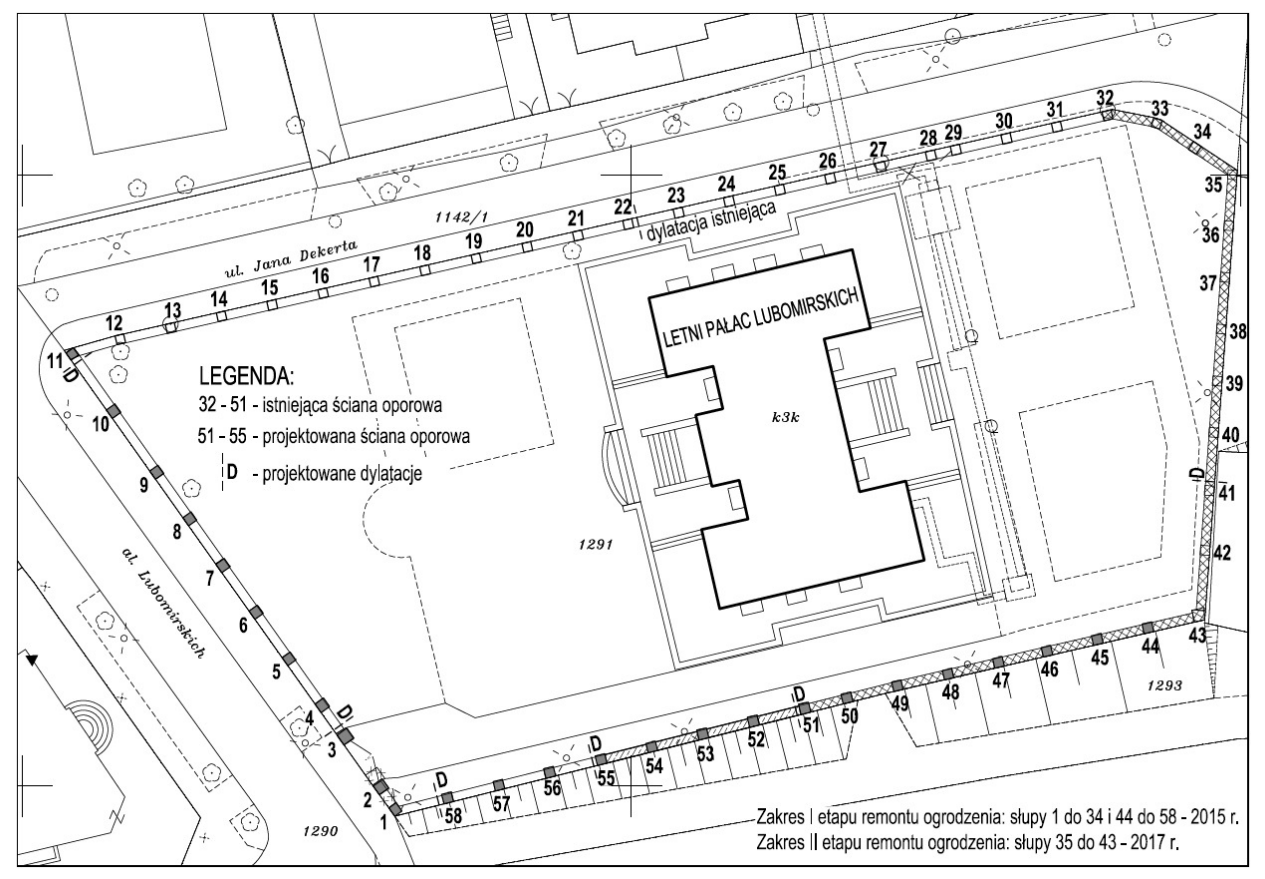

Rys. 2. Układ ogrodzenia w terenie z określeniem zakresu i etapów remontu [4]

Fig. 2. Layout of the fence in the area with define the field and stages of repair [4]

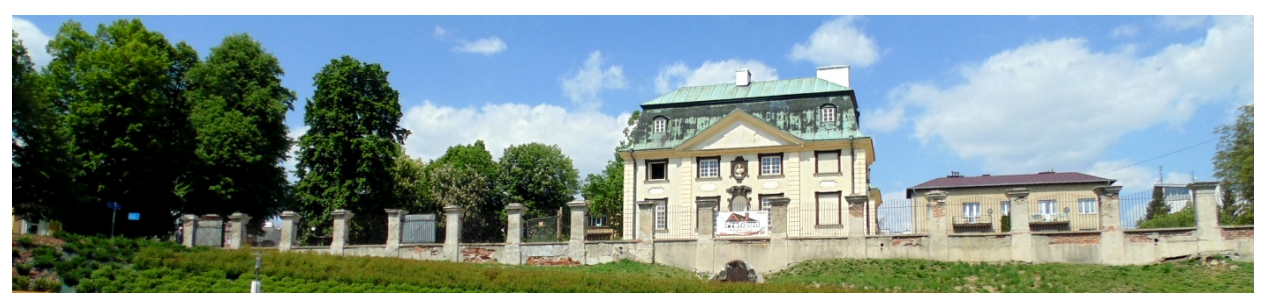

Rys. 3. Widok ogólny ogrodzenia od strony południowej - stan przed remontem

Fig. 3. General view of the fence on the south side - the state before the renovation 


\subsection{Ogrodzenie wzdłuż Al. Lubomirskich (słupy $1 \div 11$ )}

Stan techniczny słupów ceglanych i murków ceglanych pomiędzy słupami oceniono jako awaryjny (rys. 4). Degradacja elementów ogrodzenia nastąpiła w całej grubości przekroju i wzdłuż całej ich wysokości (oprócz słupa nr 2 przemurowanego w latach 80-tych). Zbyt płytkie posadowione słupów ogrodzenia skutkowało licznymi zarysowaniami, spękaniami, wychyleniami i brakiem stabilności. Stan murków przęsłowych oceniono podobnie.

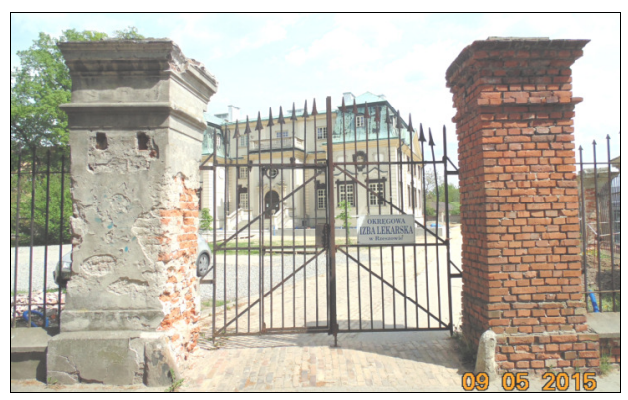

Rys. 4. Widok ogólny bramy i słupów nr 2 i 3

Fig. 4. General view of the gate and columns 2 and 3

\subsection{Ogrodzenie wzdłuż ul. Dekerta (słupy $12 \div 34$ )}

Stan techniczny tej części ogrodzenia okazał się najlepszy (rys. 5):

- posadowienie słupów prawidłowe - stan dobry,

- izolacje poziome z papy (z niewielkimi ubytkami) pomiędzy częścią murowaną słupów i fundamentami betonowymi w dobrym stanie,

- trzony słupów z ubytkami, ale nadające sie do remontu,

- część głowicowa wszystkich słupów w stanie awaryjnym, zawilgocone i przemrożone, odpadające fragmenty tynków i cegieł stanowią zagrożenie bezpieczeństwa życia i zdrowia ludzi,

- murki pomiędzy słupami - stan techniczny zły. 

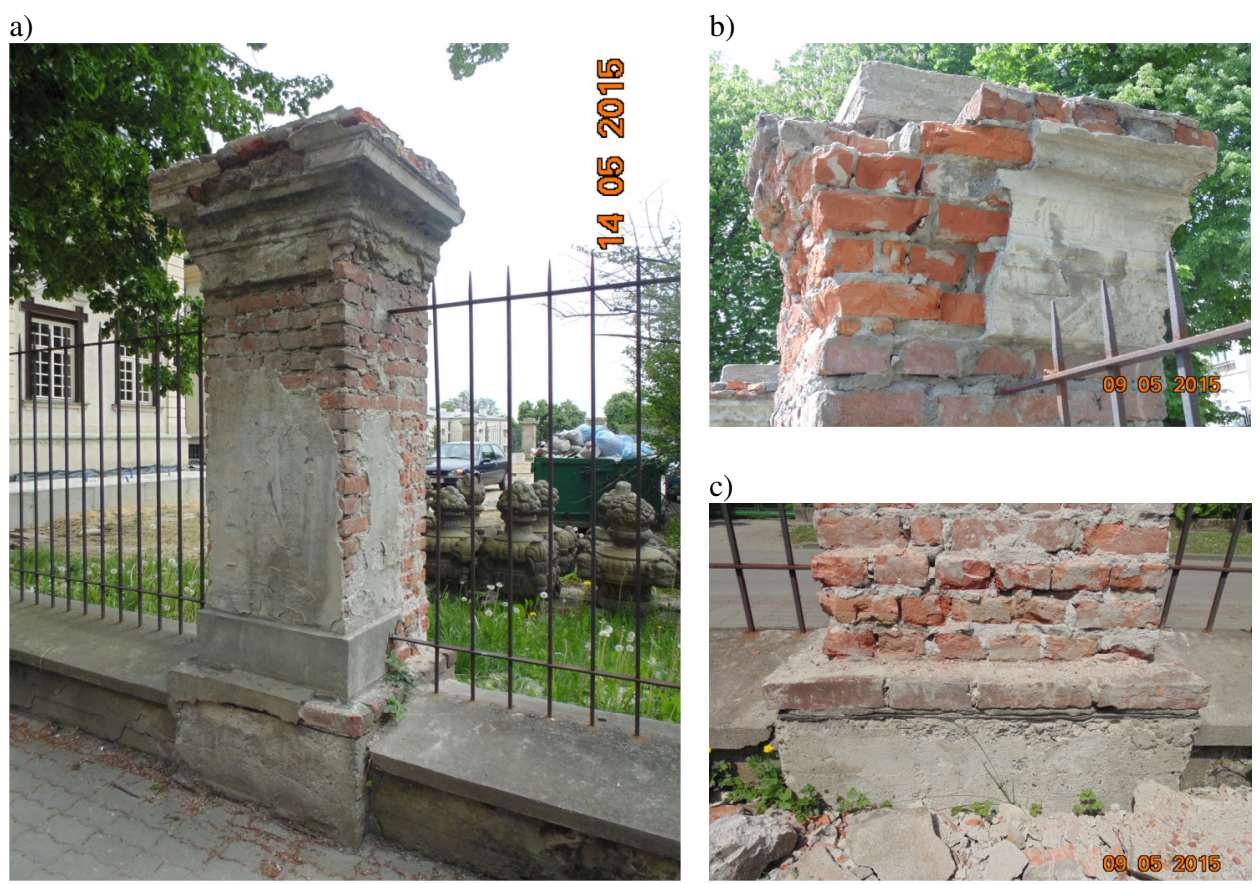

Rys. 5. Słup nr 18: a) widok ogólny od strony zewnętrznej, b) widok głowicy od strony posesji, c) widok podstawy od strony posesji

Fig. 5. Column No 18: a) general view from the outside, b) view of the head of the column on the inside, c) view of base of them on the inside

\subsection{Ogrodzenie - strona południowa (słupy $43 \div 58$ )}

Ściana oporowa wykonana z materiałów złej jakości, liczne ubytki, spękania i uszkodzenia (rys. 6, 8), stan bardzo zły - wymaga gruntownego remontu,

- brak jakiejkolwiek izolacji przeciwwilgociowej, co spotęgowało zakres zniszczeń i degradacji biologicznej wszystkich elementów ogrodzenia (rys. 6-9),

- słupy i ceglane, murki przęsłowe - bardzo zły stan techniczny - degradacja materiału tych elementów objęła równomiernie ich przekrój wzdłuż wysokości,

- odpadające luźne kawałki materiałów budulcowych ogrodzenia w tym obszarze, gdzie na teren rekreacyjny przy fontannie przychodzi bardzo wiele osób stanowią potencjalne zagrożenie zdrowia i życia ludzi. 

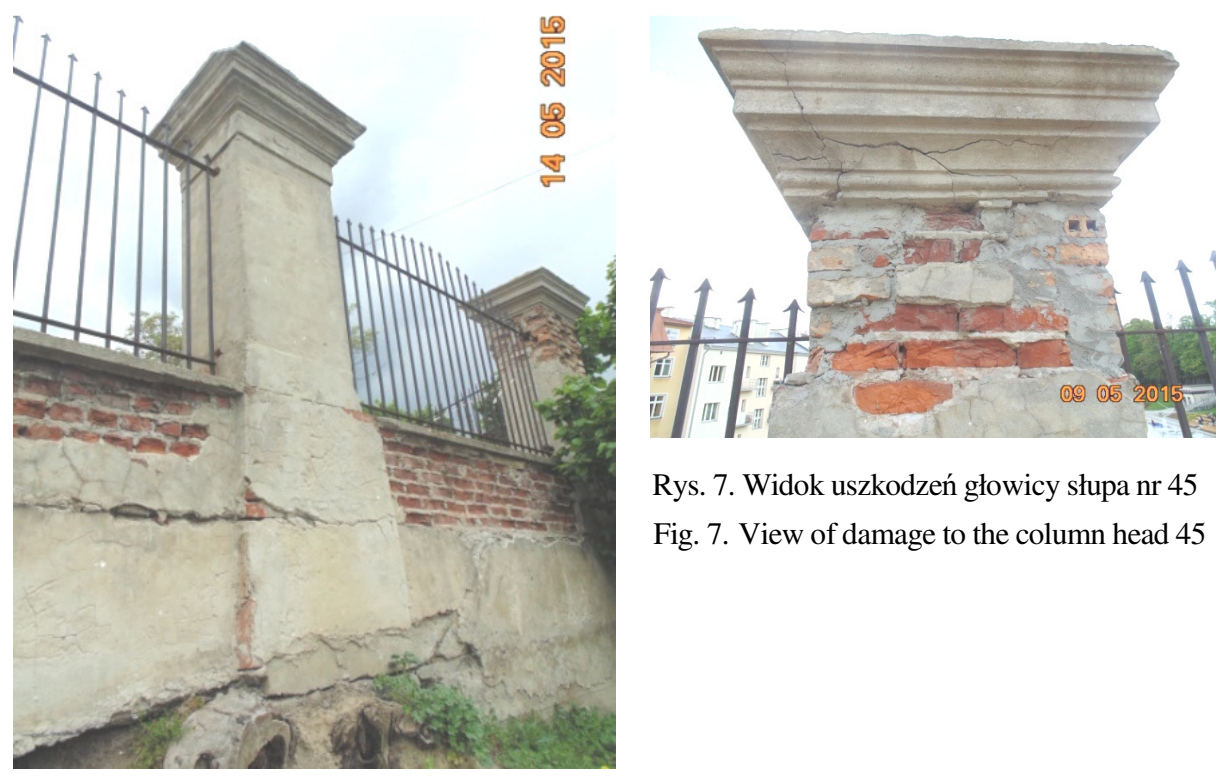

Rys. 7. Widok uszkodzeń głowicy słupa nr 45

Fig. 7. View of damage to the column head 45

Rys. 6. Zaniedbania wykonawcze ściany oporowej (pod słupem 44 pozostawiony pień drzewa), degradacja murków ceglanych

Fig. 6. Implementing negligence the retaining wall (under the column 44 left a tree trunk), the degradation of brick walls

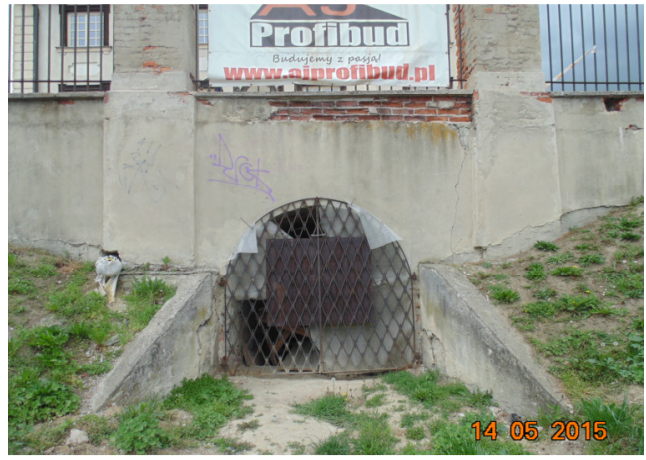

Rys. 8. Uszkodzenia pomiędzy słupami 49-50

Fig. 8. Damage in the area between columns 49-50

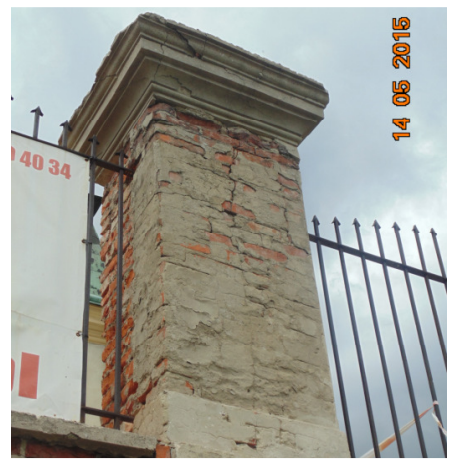

Rys. 9. Pionowe pęknięcie słupa 49

Fig. 9. The vertical crack of the column 49

\subsection{Ogrodzenie - strona wschodnia (słupy 35 - 42)}

- słupy ogrodzenia i murków przęseł 35-40, stan analogiczny jak ogrodzenia od strony ul. Dekerta,

- stan ściany oporowej, słupów i przęseł na niej posadowionych analogiczny jak ogrodzenia od strony południowej. 


\section{Zakres przeprowadzonego remontu}

Prace i zasady dotyczące całego ogrodzenia:

- jako kryterium wiodące przyjęto pozostawienie substancji istniejącej w maksymalnym możliwym zakresie,

- rozebrano wszystkie głowice słupów i ceglane murki przęsłowe,

- zabezpieczono elementy ogrodzenia przed wpływem agresji i wilgoci gruntowej oraz niekorzystnymi czynnikami atmosferycznymi,

- odtworzono ww. elementy w linii i kształcie ogrodzenia pierwotnego,

- odcinek frontowy, wszystkie naroża i wejście od ul. Dekerta zaakcentowano ustawiając na słupach ozdobne wazy,

- wykorzystano istniejące przęsła stalowe ogrodzenia - po naprawie i renowacji.

Zakres pozostałych prac dotyczący poszczególnych części ogrodzenia przedstawiono w kolejnych punktach.

\subsection{Ogrodzenie wzdłuż Al. Lubomirskich}

Rozbiórka ogrodzenia w całości i odtworzenie w następujący sposób:

- fundamenty i cokoły słupów jako żelbetowe,

- trzony słupów - jako ceglane z rdzeniem żelbetowym, a ich głowice jako żelbetowe, prefabrykowane,

- podwaliny pod przęsła ogrodzenia jako żelbetowe, oparte na cokołach słupów, zabezpieczono od wierzchu czapkami żelbetowymi prefabrykowanymi.

Słupy bramy i bramki połączono wspólną podwaliną w celu wyeliminowania wzajemnego przemieszczania się tych elementów względem siebie.

Zastosowane rozwiązania architektoniczne pokazano na rys. nr 10.

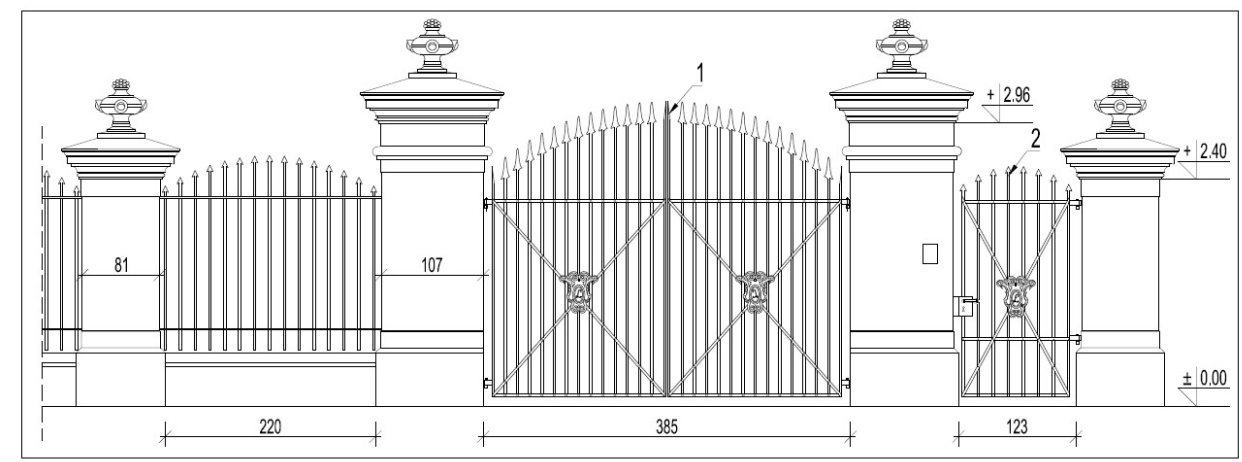

Rys. 10. Rysunek rekonstrukcji elementów ogrodzenia wzdłuż Al. Lubomirskich: 1) Brama wjazdowa wyremontowana $\mathrm{z}$ wykorzystaniem istniejących elementów stalowych, repliki herbu Lubomirskich wykuto w blasze, 2) Bramka wykonana na wzór bramki od ul. Dekerta. Autor - architekt S. Hałabuz [4]

Fig. 10. Reconstruction drawing of the fence along the Lubomirski Avenue: 1) The entrance gate restored using existing elements, a replica of the Lubomirski coat of arms carved in the steel plate, 2 ) Gateway was made on the model of gateway from the Dekert street. Author - architect S. Hałabuz [4] 


\subsection{Ogrodzenie wzdłuż ul. Dekerta}

- rozbiórka uszkodzonych, zawilgoconych i zagrzybionych głowic ceglanych wszystkich słupów oraz w całości cokołów przęseł ogrodzenia,

- skucie tynków z całej powierzchni słupów pozostawianych, uzupełnienie izolacji poziomej, uzupełnienie cegłą pełną ubytków trzonów słupów,

- naprawa betonowych cokołów słupów jednym z systemów naprawczych PCC,

- budowa nowych cokołów przęseł ogrodzenia jako żelbetowych,

- otynkowanie słupów systemem tynków renowacyjnych,

- montaż nowych, żelbetowych głowic słupów i czapek cokołów przęseł ogrodzenia.

\subsection{Ogrodzenie strona południowa}

Rozbiórka ogrodzenia posadowionego na gruncie w całości, a posadowionego na ścianie oporowej, do poziomu wierzchu ściany i odtworzenie go w zakresie:

- naprawy istniejącej ściany oporowej poprzez zszycie powstałych pęknięć, uzupełnienie podstawy ściany w obszarze, gdzie posadowiono ją na pniu ściętego drzewa(rys. 6.), reperacja ubytków korozyjnych betonu systemem zapraw naprawczych PCC,

- w obszarze dużej różnicy terenu po obu stronach ogrodzenia wybudowanie odcinka ściany oporowej celem posadowienia ogrodzenia (pomiędzy słupami 51-55), w nawiązaniu do poziomu posadowienia ściany istniejącej,

- odwodnienie obszaru za ścianą oporową z zastosowaniem drenażu.

$\mathrm{Z}$ uwagi na fakt, że stan ogrodzenia w pozostałym zakresie był identyczny jak ogrodzenia od strony Al. Lubomirskich sposób odtworzenia ogrodzenia identyczny jak wyżej wymienionego.

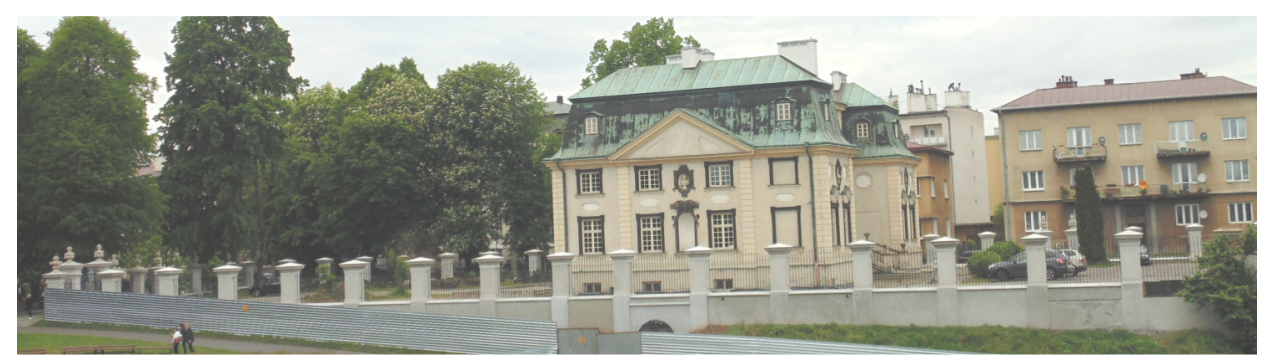

Rys. 11. Widok ogrodzenia od strony południowej - stan po remoncie

Fig. 11. View of the fence on the south side - the state after repairs 


\section{Podsumowanie}

1) Brak jakiegokolwiek zabezpieczenia przed oddziaływaniem czynników agresywnych, wcześniejsze remonty - powierzchowne i niezgodne ze sztuką budowlaną oraz brak dbałości o stan techniczny ogrodzenia poprzednich właścicieli i użytkowników Pałacu doprowadziły do całkowitego zużycia technicznego większości elementów ogrodzenia.

2) Przywrócenie stanu prawidłowego wymagało dużych nakładów finansowych i organizacyjnych oraz zaangażowania wielu osób.

3) Ścisła współpraca właściciela Pałacu, Wojewódzkiego Urzędu Ochrony Zabytków, autorów prac projektowych i eksperckich, ścisły nadzór nad prowadzonymi pracami restauracyjnymi, staranne wykonawstwo oraz znacząca pomoc finansowa Prezydenta Miasta Rzeszowa pozwoliły doprowadzić ogrodzenie terenu do stanu prawidłowego, uzyskać jego lekką formę, podkreślającą kunszt bryły budynku (rys. 11).

\section{Literatura}

[1] Kotula F.: Tamten Rzeszów, Wydawnictwo LIBRI RESSOVIENSES, Rzeszów 1997.

[2] Karta Ewidencji Zabytku obiektu zabytkowego "Zespół Pałacu Letniego Lubomirskich" wypełniona 31.VIII.1959r. przez T. Żurawską.

[3] http://www.rzeszow.pl/miasto-rzeszow/historia/zabytki-rzeszowa/palac-letnilubomirskich \{dostęp 30.04.2016 r.\}.

[4] Ekspertyza stanu technicznego ogrodzenia Letniego Pałacu Lubomirskich. opracowana przez WIK K. Wróbel i W. Kubiszyn w maju 2015 r.

\section{REPAIRS OF HISTORICAL FENCE OF THE SUMMER LUBOMIRSKI PALACE IN RZESZÓW}

\section{S u m m a r y}

Lubomirski Summer Palace and its surroundings is one of the most valuable, not sacred monuments of Rzeszow. In 2013 it was bought by the Regional Medical Chamber from the last private owners and was allocated for its headquarters. Comprehensive overhaul of whole facility was planned, repair works of the building are currently in progress. In 2015 Medical Association conducted a thorough renovation of the fence, necessary because of its catastrophic condition. The main objective was to preserve existing substance to the maximum possible extent. Three sides of the fence, apart from the east side, were repaired and protected against the effects of ground and atmospheric moisture. Renovation consisted of repairing and strengthening the columns along the Dekerta street, strengthening and protection against further damage the existing retaining wall and its extension, necessary to maintain the stability of the fence. There was also performed a reconstruction of remaining columns and brick walls between them. All the columns were secured with reinforced concrete heads in a shape with replicates the existing ones. Front section, all the corners and entrance from the Dekerta street were accented by setting decorative vases on each columns. New gateway was made using old elements, its leaves were decorated with replicas of the Lubo- 
mirski coat of arms carved in the steel plate. Small gate next to the main one was made by mapping the existing one from the Dekerta street. The existing steel fence spans were reused after their repair and renovation. The paper describes in details the technical condition of the fence before the renovation, the way and range of the performed repair work.

Keywords: technical condition, protection, biological corrosion, column, retaining wall

DOI:10.7862/rb.2016.237

Przestano do redakcji: 20.04.2016 $r$.

Przyjęto do druku: 30.11.2016 r. 